\title{
Dissolved organic matter dynamics in the pristine Krka River estuary (Croatia)
}

\author{
Saša Marcinek ${ }^{1, *}$, Chiara Santinelli ${ }^{2}$, Ana-Marija Cindrić ${ }^{1}$, Valtere Evangelista ${ }^{2}$, Margherita Gonnelli ${ }^{2}$, \\ Nicolas Layglon ${ }^{3}$, Stephane Mounier ${ }^{3}$, Veronique Lenoble ${ }^{3}$ and Dario Omanović ${ }^{1}$ \\ ${ }^{1}$ Ruđer Bošković Institute, Center for Marine and Environmental Research, Zagreb, Croatia \\ ${ }^{2}$ CNR - Biophysics Institute, Pisa, Italy \\ ${ }^{3}$ Mediterranean Institute of Oceanology, ECEM, Toulon University, La Garde, France \\ *Corresponding author: smarcin@irb.hr
}

\section{Abstract}

The karstic Krka River is characterized by having lower dissolved organic carbon (DOC) concentrations $(\sim 30 \mu \mathrm{M})$ than coastal seawater $(\sim 60 \mu \mathrm{M})$. This peculiarity, together with the pristine nature of this area, makes the Krka River estuary a natural laboratory where it is possible to discriminate among the different dissolved organic matter (DOM) sources (riverine, marine and produced in-situ) and to study the main processes of DOM production and removal. The hypothesis behind this work is that in winter, due to the high discharge of the river, most of the DOM has a terrestrial signature, whereas in summer autochthonous DOM compose the main fraction of the DOM pool because of the reduced discharge, the high temperature and primary production. Our data shows that DOM in the river mainly consists of terrestrial molecules, as suggested by the high chromophoric content and low spectral slope $\left(S_{275-295}\right)$ values, as well by the predominance of humic-like substances. DOM in the seawater features the concentration and optical properties of the "typical" marine DOM from open sea waters. In summer, low riverine discharge and high temperature promote the intense biological activity, with an increase in DOC concentrations of up to $148 \mu \mathrm{M}$, resulting in a non-conservative behavior of DOM in the estuary. The high stratification combined with a decoupling between production and removal processes can explain the observed DOM accumulation. In the bottom layer DOM was released and quickly removed when oxygen was available, whereas in hypoxic waters the production of DOC, chromophoric DOM (CDOM) and fluorescent DOM (FDOM) was linearly related to oxygen consumption. Our work highlights the need of further studies combining chemical and biological information in order to gain new insights into the main processes responsible for DOM dynamics in this system.

Keywords: Chromophoric dissolved organic matter (CDOM), Dissolved organic carbon (DOC), Excitation-emission matrices (EEMs), PARAFAC, Krka River estuary, Stratified estuary, In-situ production, Terrestrial DOM 


\section{Introduction}

33 Dissolved organic matter (DOM) in the oceans contains the largest pool of reduced carbon on Earth: the 34 dissolved organic carbon (DOC) (Hansell et al., 2009). With an inventory of $662 \mathrm{Pg} \mathrm{C}$, the DOC pool in the oceans is comparable to the amount of $\mathrm{CO}_{2}$ in the atmosphere. It, therefore, plays a crucial role in the global carbon cycle. In the oceans, DOM concentration is the result of in-situ biological processes of production and removal and its cycle controls the functioning of marine ecosystems (Carlson and Hansell (2015) and literature therein). Data on $\mathrm{DOC} \delta^{13} \mathrm{C}$ support that most of the DOM in the open oceans is autochthonous (Beaupré (2015) and literature therein; Druffel et al. (1992)). Rivers (Fichot and Benner, 2014; Mulholland, 2003; Raymond and Spencer, 2015; Retelletti Brogi et al., 2020), the atmosphere (Galletti et al., 2020; Miller et al., 2009; Pulido-Villena et al., 2008; Vicente et al., 2012), and sediments (Burdige and Komada (2015) and literature therein) represent important sources of allochthonous DOM to the oceans. Chromophoric/colored DOM (CDOM) is the fraction of DOM capable of absorbing light at the UV and visible wavelengths. A fraction of CDOM, called fluorescent DOM (FDOM), can emit part of the absorbed light as fluorescence. Although CDOM represents a small and not well-defined fraction of the entire DOM pool, it is of vital importance for the marine ecosystem, since it is one of the main factors determining the light availability (penetration depth) in clear open ocean waters (Stedmon and Nelson, 2015). DOM composition is chemically very complex and cannot be easily characterized (Repeta, 2015). CDOM and FDOM give indirect qualitative information about the DOM pool, such as average aromaticity degree and molecular weight as well as the occurrence of humic-like, fulvic-like and proteinlike substances. These information can enhance our understanding of the main sources and processes

52 affecting DOM distribution (Dainard et al., 2015; Fellman et al., 2011; Galletti et al., 2019; Lee et al., 2018; Li and Hur, 2017; Yamashita et al., 2011; Zhou et al., 2019). River input is a relevant source of DOM for the coastal areas (Raymond and Spencer, 2015; Retelletti Brogi et al., 2020), where an inverse relationship is usually observed between DOC and salinity ( $\underline{\mathrm{Li} \text { et } \mathrm{al} ., 2019}$; Massicotte et al., 2017; Retelletti Brogi et al., 2015; Zhou et al., 2019). Estuaries are the transition zones, where photochemical and/or biological processes can transform the riverine DOM before its input to the coastal ocean (Retelletti Brogi et al., 2015; Santos et al., 2014; Søndergaard et al., 2003); here, allochthonous DOM can be partially removed and replaced by the DOM produced by autochthonous processes (Fellman et al., 2011; Gonnelli et al., 2013; Lee and Kim, 2018; Osburn et al., 2019; Raymond and Spencer, 2015). These processes are particularly relevant in estuaries largely controlled by changes in river flow, during periods 
et al. (2014) found that in Neuse River estuary, lower inputs of allochthonous DOM and increased water residence times allowed for the net production of autochthonous DOM. This work also showed that shallow microtidal estuaries can generate significant amounts of autochthonous DOM which can compose the main fraction of the DOM pool during low river flow. These environments are highly dynamic and influenced by multiple processes, making it very difficult to discriminate among different inputs and processes.

The main goal of this study is to disentangle 3 different DOM pools (riverine, marine and produced insitu by biological activity) and to investigate their spectral characteristics, including fluorescence excitation-emission matrices (EEMs) and spectral slope curves (SSCs), in a low-DOM karst system: the Krka River estuary. The hypothesis is that in winter, due to the high river discharge, most of DOM has a terrestrial signature, whereas in summer in-situ production of DOM dominates because of the reduced river discharge, the high temperature and primary production. Due to the expected low DOM concentration in the Krka River it will be possible to discriminate among the different DOM sources (riverine, marine, produced in-situ) and to study the main processes of DOM production and removal in the estuary.

\subsection{Krka River estuary: a case study for DOM dynamics in low DOM systems}

The Krka River is one of the major karstic rivers flowing to the middle Adriatic coast, along with the rivers Zrmanja and Cetina. Most of the Croatian coast is covered in limestone prone to karstation. The process of karstation forms tufa barriers which create lakes and waterfalls along the river flow. The Krka National Park occupies the lower part of the Krka River and the upper part of the estuary, and the tufa barriers and waterfalls are its basic natural phenomenon. Anthropogenic influence along the lower river flow is negligible, the vegetation is scarce and the tufa barriers and lakes retain much of the organic material and sediment load (Cindric et al., 2015; Cukrov et al., 2008; Legovic et al., 1994; Scribe et al., 1991), making the freshwater entering the estuary exceptionally clean and comparable to the world's most pristine riverine systems. The very low concentration of trace elements support the cleanliness of the Krka River water (Cindric et al., 2015; Cukrov et al., 2008; Legovic et al., 1994; Scribe et al., 1991). With an annual nutrient input of $55 \times 10^{6} \mathrm{~mol} \mathrm{~N}, 1.8 \times 10^{6} \mathrm{~mol} \mathrm{P}$ and $36.4 \times 10^{6} \mathrm{~mol} \mathrm{Si}$, the estuary is a P-limited system (Grzetic et al., 1991; Svensen et al., 2007). The estuary has a total length of $23.5 \mathrm{~km}$, and it begins after the last and biggest waterfall: Skradinski Buk (46 m high) (Fig. 1). As a result of its specific geography and low tidal influence (30-40 cm (Legovic et al., 1994)), the estuary is permanently stratified. 
94

The surface fresh/brackish water layer (FWL) is separated from the sea water layer (SWL) by a sharp halocline formed at a depth between 1.5 and $5 \mathrm{~m}$. Extension of the surface layer depends on the Krka River discharge, which has an average annual value of $52.9 \mathrm{~m}^{3} \mathrm{~s}^{-1}$ (Buzancic et al., 2016). In the widest parts of the estuary, during high river flow, seawater renewal times range between 50 and 100 days, whereas, during low river flow, seawater renewal time is up to 250 days (Legovic, 1991). While the Krka River estuary is in general well characterized on its hydrology, biological status and trace metals behavior (Cetinic et al., 2006; Cindric et al., 2015; Knežević et al., 2019; Legovic et al., 1991a; Legovic et al., 1991c; Pađan et al., 2019a; Pađan et al., 2019b; Supraha et al., 2014; Svensen et al., 2007), few papers report data on DOC (Cindric et al., 2015; Laureillard and Saliot, 1993; Louis et al., 2009; Svensen et al., 2007; Svetličić et al., 1991) and to the best of our knowledge, no information about CDOM and FDOM dynamics is reported. This is the first study focused on the organic matter dynamics in the Krka River estuary.

\section{Materials and methods}

\subsection{Sampling stations and samples collection}

Samples were collected at 16 stations along the estuary, from Skradinski Buk waterfall to the coastal area, south of the Island Zlarin (Fig. 1). Samples were collected at 2 depths (surface and bottom) in winter (February $12^{\text {th }}, 2019$ ), during high Krka River flow, and summer (July 24 ${ }^{\text {th }}, 2019$ ), during low Krka River flow (Fig. S1). At selected stations (station M1, in front of Martinska marine station, in February 2019; stations 5, M1 and M2, located in the mussel farm, in July 2019) (Fig. 1), samples were collected at 6 depths, chosen from the vertical salinity profiles ( 2 in FWL, 2 at freshwater-seawater interface and 2 in SWL). On July $22^{\text {nd }} 2019$, six additional samples were collected in the Krka River, at stations K1-K6 (Fig. S2). The sampling in the river was carried out when a phytoplankton bloom occurred in the Visovac Lake (station K4), preceding the Skradinski Buk waterfalls.

In order to investigate the processes above and below the halocline, samples were separated according to the salinity in the freshwater layer (FWL; $S<20$ ) and the seawater layer ( $\mathrm{SWL}$; $>37$ ). These two groups include all the samples. In order to characterize DOM in river water and seawater, samples were further divided. For river water (RW), we took into consideration only the samples collected in the surface layer between station 0 and station $7(S<1)$ in February and at stations $K 1$ and $2(S<1)$ in July. For seawater (SW), we took into consideration only the samples characterized by $S>38$ in both periods. Finally, for the mixing area, we took into consideration only the samples characterized by salinity ranging from 1.8 to 
36. Because of the influence of phytoplankton bloom at station K4 on DOM quality in downstream waters, stations K1-2 were used as representative for riverine DOM in July, instead of stations 0-7, as in February.

Vertical profiles of physical-chemical parameters (salinity, temperature, oxygen saturation, chlorophyll $a$ (chl-a)) were measured by using the EXO2 multiparameter CTD probe (YSI). The sensors of the multiprobe were checked and calibrated before each field campaign. For each sensor (except temperature and depth) a factory-recommended two-point calibration was performed, within $3 \mathrm{~m}$ above the sea level. Apparent oxygen utilization (AOU) was calculated using the Ocean Data View software (ODV, version 5.1.7) (Schlitzer, 2002), as the difference between the oxygen at saturation and the oxygen measured in-situ (Garcia et al., 2013).

Samples were collected using van Dorn-type horizontal sampler (alfa or beta, Wildco), and immediately filtered on-board through $0.22 \mu \mathrm{m} \mathrm{CA}$ filters (Sartorius) by using pre-cleaned syringes $\left(5 \% \mathrm{v} / \mathrm{v} \mathrm{HNO}_{3}\right.$, rinsed 3 times with Mili-Q water). Samples were stored at $4{ }^{\circ} \mathrm{C}$ in pre-cleaned $(1 \% \mathrm{v} / \mathrm{v} \mathrm{HCl}$, rinsed 3 times with Mili-Q water) polycarbonate (Nalgene) bottles until the analysis, carried out within one month, since repeated tests for both, absorbance and fluorescence, showed no change in the spectra over 1 month. Syringes, filters and bottles were rinsed 3 times with the sample before its collection. The filtration system (syringe + filter) was selected after repeated tests with Milli-Q water, since the water filtered through the pre-cleaned system was not contaminated with DOC, and it showed the same UV/Vis spectra and EEM before and after the filtration.

The vertical distribution of physical (salinity and temperature), chemical (oxygen) and biological (chl- $a$ ) parameters in the estuary were interpolated using DIVA gridding in the Ocean Data View software (Figs. 2-3 and Figs. S3-4), whereas DOC, CDOM and FDOM parameters (Figs. S5-8) are shown as colored dots since the number of the data points was not sufficient for good interpolation.

\subsection{Dissolved organic carbon measurements}

DOC concentration was determined by high temperature catalytic oxidation using a Shimadzu TOC-VCSN carbon analyzer. Prior to oxidation, samples were acidified with $2 \mathrm{M}$ high purity $\mathrm{HCl}$ and purged for 3 min with pure air to remove inorganic carbon. In order to achieve satisfying analytical precision ( $\pm 1 \%)$, up to 5 replicate injections were performed. At the beginning and the end of each analytical day, the system blank was measured using Milli-Q water and the functioning of the instrument was checked by comparison of data with DOC Consensus Reference Material (CRM) (Hansell, 2005) (batch \#18/08-18, 
measured concentration: $43.7 \pm 0.8 \mu \mathrm{M}, \mathrm{n}=14$ and batch \#19/03-19, measured concentration: $40.5 \pm$ $0.6 \mu \mathrm{M}, \mathrm{n}=8)$. The external calibration curve was measured with potassium hydrogen phthalate as the organic standard. For more details please refer to Santinelli et al. (2015).

\subsection{Absorbance measurements}

UV-Vis spectra were measured using a JASCO Spectrophotometer V-550 with 10-cm Suprasil quartz cuvettes. The scan was performed between 230 and $800 \mathrm{~nm}$ using a $1000 \mathrm{~nm} / \mathrm{min}$ scan rate and $0.5 \mathrm{~nm}$ resolution. The spectrum of Milli-Q water, measured in the same conditions, was used as a blank and subtracted from each sample. In order to minimize light scattering interferences, baseline subtraction of average absorption between 650 and $700 \mathrm{~nm}$ was performed. Absorbance at $254 \mathrm{~nm}\left(A_{254}\right)$ was used as representative of CDOM pool and expressed as the absorption coefficient $\left(a_{\mathrm{CDOM}(254)}\right)$ in Naperian units (Eq. 1)

$$
a_{\mathrm{CDOM}(254)}=2,303 \cdot \frac{A_{254}}{l}
$$

where $I$ is the path length expressed in meters. The specific UV absorbance at $254 \mathrm{~nm}\left(\mathrm{SUVA}_{254}\right)$ was calculated by dividing the decadic absorption coefficient at $254 \mathrm{~nm}$ by DOC concentration $\left(\mathrm{m}^{2} \mathrm{~g}^{-1}\right)$ and used as indicator of percentage of CDOM in the total DOM pool (Stedmon and Nelson, 2015). The spectral slope over a $275-295 \mathrm{~nm}$ spectral range $\left(S_{275-295}\right)$ was calculated using the exponential model (Eq. 2) and used as proxy for average molecular weight (MW), aromaticity and humification degree (Helms et al., 2008) as well as a proxy of terrigenous DOC (Fichot and Benner, 2012).

$$
a_{\lambda}=a_{\lambda_{0}} \cdot e^{-S\left(\lambda-\lambda_{0}\right)}
$$

where $a_{\lambda}$ is the absorption coefficient at a specific wavelength and $\lambda_{0}$ is the reference wavelength.

In order to study spectral differences among DOM pools, wavelength distribution of spectral slopes expressed as a spectral slope curve (SSC) was used (Loiselle et al., 2009). Average SSCs of freshwater ( $n=$ 9) and seawater samples $(n=6)$ as well as SSCs for 3 typical samples were obtained by calculating the spectral slopes for $20 \mathrm{~nm}$ intervals across a 200-500 nm wavelength range. All the above reported calculations were performed using the newly purpose-developed software package, ASFit, described in detail in Omanović et al. (2019).

\subsection{Fluorescence measurements}


185

186

Fluorescence excitation-emission matrices (EEMs) were recorded using the Aqualog spectrofluorometer (Horiba- Jobin Ivon) in $1 \times 1 \mathrm{~cm}$ quartz cuvettes. EEMs were scanned at the excitation wavelengths range of 250-450 nm with $5 \mathrm{~nm}$ increments and emission wavelengths range of 212-619 nm with $3 \mathrm{~nm}$ increments. Excitation and emission slit-widths were both set at $5 \mathrm{~nm}$. The blanks were checked every 5 samples by measuring the EEM of Milli-Q water. The blank was not subtracted from the samples, since the fluorescence intensities measured in Milli-Q were negligible if compared to the fluorescence intensity measured in the samples and blank subtraction increased the noise of the EEMs. Fluorescence intensity was normalized to Raman units (R.U.) using the daily-measured Raman peak of Mili-Q water ( $\lambda_{\mathrm{ex}}$ $=350 \mathrm{~nm}, \lambda_{\mathrm{em}}=371-428 \mathrm{~nm}$ ) (Lawaetz and Stedmon, 2009). Parallel factor analysis (PARAFAC) was applied to identify the different components in the FDOM pool by using the decomposition routines for EEMs (drEEM) toolbox (version 0.2.0 for MATLAB (R2016a) (Murphy et al., 2013). PARAFAC was applied to the complete dataset containing all the EEMs (Dataset 1: 102 EEMs). In order to gain additional information about the occurrence of different components depending on the season, Dataset 1 was split into 2 datasets according to the season: Dataset 2 (February 2019: 38 EEMs) and Dataset 3 (July 2019: 64 EEMs). Validated fluorescent components were identified as humic-like and protein-like substances by comparison with similar components reported in the literature and matching spectra obtained from the OpenFluor database (Murphy et al., 2014) (Table S1). Excitation and emission spectra of the protein-like component was also compared to the excitation and emission spectra of commercial tryptophan from Sigma-Aldrich (Figs. S9 and S10).

\section{Results}

\subsection{Environmental parameters}

In both seasons, two layers were clearly visible in the salinity vertical distribution: the $\mathrm{FWL}(\mathrm{S}<20)$ and the SWL (S>37) (Fig. 2A and C). In winter, water with low salinity $(S<8)$ was clearly visible in the upper 5 m until station 12, located very close to the sea. In contrast, in summer, due to very low river discharge, the freshwater occupied the upper $1.5 \mathrm{~m}$ and mixing with marine water started upstream in the estuary (station 4). In summer, stations 5 to 12 were therefore characterized by higher salinity $(S=15-27)$ than in winter $(S=0-8)$.

The temperature showed an inverse distribution in the 2 seasons. In February, the RW and most of the FWL were characterized by an average temperature of $\sim 10{ }^{\circ} \mathrm{C}$, whereas the $\mathrm{SW}$ and the SWL were warmer (average temperature of $13{ }^{\circ} \mathrm{C}$ ), with a maximum of $15{ }^{\circ} \mathrm{C}$ in the shallowest part of the estuary 
216 (stations 2-4) (Fig. 2B and D and Table 1). In July, the FWL was characterized by the highest temperature $217\left(26^{\circ} \mathrm{C}\right)$, the RW had average temperature of $19^{\circ} \mathrm{C}$, whereas the SW was colder (average temperature of $21817^{\circ} \mathrm{C}$ ) (Fig. 2B and D and Table 1).

219 In February, oxygen saturation closely resembled the distribution of both, salinity and temperature, with 220 oversaturation $(>100 \%)$ at the freshwater-seawater interface, a minimum $(70-75 \%)$ at stations $2-4$ below $2215 \mathrm{~m}$ and average values of $90 \%$ in SW (Fig. 3A). In July, oxygen oversaturation (120-160\%) was observed 222 in the river (stations K3-K6), and in the subsurface layer (1-5 m) at stations 2-9 and in the Šibenik bay 223 (station 10) at about $3 \mathrm{~m}$ (Fig. 3C). Hypoxia (<38\%) occurred in the bottom layer of station 1, supporting 224 the long residence time of this water (Cindric et al., 2015; Legovic, 1991).

225 As expected, chl- $a$ was lower in February $(<3.5 \mu \mathrm{g} / \mathrm{L})$ than in July $(4-5 \mu \mathrm{g} / \mathrm{L})$ (Fig. 3B and D). Surprisingly, 226 in July, the highest chl-a values were not recorded at the halocline but close to the bottom with a 227 maximum $(7 \mu \mathrm{g} / \mathrm{L}$ ) in the middle of the estuary (station 8) between 20 and $23 \mathrm{~m}$. In the Visovac lake 228 (station K4), where a phytoplankton bloom was observed prior to our sampling campaign, both, chl-a and dissolved oxygen, showed high values.

230

DOC values ranged between 35 and $76 \mu \mathrm{M}$ in February and 30 and $148 \mu \mathrm{M}$ in July (Fig. S5A and C). The lowest values were observed in the RW in both seasons (36 $\mu \mathrm{M}$ in February and $30 \mu \mathrm{M}$ in July) (Table 1).

234 These values are at least 3 times lower than in the other Mediterranean rivers, especially compared to the major Mediterranean rivers (Tevere, Po, Ebro and Rhone) with DOC values of up to $220 \mu \mathrm{M}$

236 (Santinelli, 2015). An extreme case is the Arno River with values of up to 10 times higher $(309 \pm 90 \mu M)$ 237 than the Krka River (Retelletti Brogi et al., 2020; Retelletti Brogi et al., 2015). The values reported in our 238 study are lower than those measured by Strmečki et al. (2018) in the upper reach of the Krka River 239 (Brljan Lake) in March, May, June, September and November of 2011 and in January 2012 (45-127 $\mu \mathrm{M})$. 240 The values reported in our study are similar to those measured at the head of the Krka River estuary in 241 February $2012(35 \mu \mathrm{M})$ (Cindric et al., 2015). At station 0, the DOC was $17 \mu \mathrm{M}$ higher in July (55 $\mu \mathrm{M})$ than 242 in February (38 $\mu \mathrm{M})$. Cindric et al. (2015) also observed seasonal differences in the DOC concentrations 243 at station 0 , as a consequence of higher biological activity in summer.

244 The SW was characterized by average DOC concentrations of $63 \mu \mathrm{M}$ in February and $60 \mu \mathrm{M}$ in July (Table 245 1). These values are comparable to DOC concentrations reported in open waters of the Mediterranean 246 Sea (Catala et al., 2018; Galletti et al., 2019; Santinelli, 2015; Santinelli et al., 2010). In July, a marked 
increase in DOC values was observed in correspondence with the mixing between freshwater and seawater (stations 2-13), with a maximum (up to $148 \mu \mathrm{M}$ ) at stations 5-7. The average DOC concentration in the mixing area in July was $101 \mu \mathrm{M}$, while in February it was only $51 \mu \mathrm{M}$ (Table 1).

\section{3. $C D O M$}

In both seasons, $a_{\mathrm{CDOM}(254)}$ showed higher average values in RW $\left(2.6 \mathrm{~m}^{-1}\right.$ in February and $2.2 \mathrm{~m}^{-1}$ in July) than in SW (1.6 m $\mathrm{m}^{-1}$ in February and $1.7 \mathrm{~m}^{-1}$ in July) (Fig. S5B and D and Table 1). A marked increase in $a_{\mathrm{CDOM}(254)}$ was observed in the mixing area, where it showed average values of $2.8 \mathrm{~m}^{-1}$ in winter and 3.6 $\mathrm{m}^{-1}$ in summer (Table 1). In July, its maximum $\left(6.3 \mathrm{~m}^{-1}\right)$ was observed at station 1 in the bottom hypoxic area (Table 1).

In both seasons, $S_{275-295}$ was lower in the RW (average values of $16.8 \mu \mathrm{m}^{-1}$ in February and $16.6 \mu \mathrm{m}^{-1}$ in July) than in the SW (average values of $30.5 \mu \mathrm{m}^{-1}$ in February and $29.3 \mu \mathrm{m}^{-1}$ in July) (Fig. S6A and C and Table 1). The values of $S_{275-295}$, observed in RW, are common for terrestrially derived CDOM in real systems (Fichot and Benner, 2012; Garcia et al., 2018; Joshi et al., 2017; Soto Cárdenas et al., 2017), and indicate that DOM in the RW was characterized by high average MW and high aromaticity degree. The higher average $S_{275-295}$ observed in the mixing area in summer $\left(25.8 \mu \mathrm{m}^{-1}\right)$ as opposed to the winter (19.4 $\mu \mathrm{m}^{-1}$ ) suggests CDOM photodegradation in summer, leading to a lower average molecular weight of CDOM. In July, in the bottom hypoxic area (station 1), $S_{275-295}$ was low $\left(17.4 \mu \mathrm{m}^{-1}\right)$ (Fig. S6C and Table 1), suggesting the occurrence of material with a high MW and aromaticity degree (Helms et al., 2008). As expected, SUVA 254 was higher in RW (average values of $2.7 \mathrm{~m}^{2} \mathrm{~g}^{-1}$ in February and July) than in SW (average values of $0.9 \mathrm{~m}^{2} \mathrm{~g}^{-1}$ in February and $1.0 \mathrm{~m}^{2} \mathrm{~g}^{-1}$ in July) (Fig. S6B and D and Table 1), suggesting that the DOM pool was characterized by higher chromophoric content in the RW. In RW, SUVA 254 was only $10-30 \%$ lower than in the pristine Epulu River (Congo) $\left(3-3.6 \mathrm{~m}^{2} \mathrm{~g}^{-1}\right.$ ), that is characterized by the highest DOC and lignin phenol concentrations of any rainforest (Spencer et al., 2010).

\subsection{FDOM}

\subsubsection{EEMs}

EEMs in RW (station 0 in February) had 2 main peaks $\left(\lambda_{\text {ex }} / \lambda_{\text {em }}=250 / 400-500 \mathrm{~nm}\right.$ and $\lambda_{\text {ex }} / \lambda_{\text {em }}=315 / 400$ $460 \mathrm{~nm}$ ), that can be related to humic-like fluorophores (peaks $A$ and $M$ according to Coble (1996) and $\alpha^{\prime}$ and $\beta$ according to Parlanti et al. (2000)) (Fig. 4). EEMs in SW (station 15-surface in both periods) had 1 
277

278

279

280

281

main peak $\left(\lambda_{\mathrm{ex}} / \lambda_{\mathrm{em}}=275 / 340 \mathrm{~nm}\right.$ ) analogous to protein-like (tryptophan) fluorophore (peak T according to Coble (1996) and $\delta$ according to Parlanti et al. (2000)) and a small peak ( $\lambda_{\text {ex }} / \lambda_{e m}=250 / 400-500 \mathrm{~nm}$ ) that can be attributed to humic-like fluorophores (Fig. 4).

The EEM of the sample collected at station K4 was different from the others, with very high fluorescence intensity and 3 peaks $\left(\lambda_{\mathrm{ex}} / \lambda_{\mathrm{em}}=250 / 400-460 \mathrm{~nm}, \lambda_{\mathrm{ex}} / \lambda_{\mathrm{em}}=275 / 340 \mathrm{~nm}\right.$ and $\lambda_{\mathrm{ex}} / \lambda_{\mathrm{em}}=330 / 380-420 \mathrm{~nm}$; peaks $A, T$ and $M$ according to Coble (1996) and $\alpha^{\prime}, \delta$ and $\beta$ according to Parlanti et al. (2000)), suggesting the in-situ production of both humic-like and protein-like substances during the bloom (Fig. 4). Finally, the EEM of the sample collected in the hypoxic waters (station 1-bottom) showed the highest fluorescence intensity and 3 peaks $\left(\lambda_{\text {ex }} / \lambda_{\text {em }}=250 / 400-460 \mathrm{~nm}, \lambda_{\text {ex }} / \lambda_{\text {em }}=275 / 340 \mathrm{~nm}\right.$ and $\lambda_{\text {ex }} / \lambda_{\text {em }}=$ 315/380-420 nm), with the predominance of humic-like fluorescence (peak A according to Coble (1996) and $\alpha^{\prime}$ according to Parlanti et al. (2000)) (Fig. 4).

\subsubsection{PARAFAC components}

A 3-component model was validated by the PARAFAC applied to the complete dataset (Dataset 1). Excitation and emission spectra of each component are reported in Fig. S9. Component 1 (C1) $\left(\lambda_{\mathrm{ex}} / \lambda_{\mathrm{em}}=\right.$ 305/416) was identified as microbial humic-like substances, component 2 (C2) ( $\left.\lambda_{\mathrm{ex}} / \lambda_{\mathrm{em}}=275(345) / 479\right)$ as terrestrial humic-like substances and component 3 (C3) $\left(\lambda_{\text {ex }} / \lambda_{\text {em }}=275 / 344\right)$ as protein-like (tryptophan) substances.

In the RW, the average fluorescence intensity of $\mathrm{C} 1$ and $\mathrm{C} 2$ was $40-50 \%$ lower in July than in February (Table 1), whereas C3 was 75\% higher in July than in February. In both seasons, the C1 and C2 were notably lower in SW than in RW, whereas C3 showed similar values (Table 1). In the mixing area, C3 represented $19.4 \%$ of total fluorescence in February and $43.6 \%$ in July. In contrast, humic-like fluorescence (C1 and C2) was significantly lower in July than in February (Table 1).

EEMs in Dataset 1 were split according to the season and PARAFAC was run separately for the 2 subdatasets in order to investigate if the number and importance of components changed depending on the season. When only the EEMs from February were taken into consideration (Dataset 2), PARAFAC validated the same 3 components as in the complete dataset (Dataset 1 ), whereas, when only the EEMs from July were taken into consideration (Dataset 3), a 6-component model was validated. The model included 3 new components identified as marine humic-like, terrestrial fulvic-like and PAH-like (Fig. S10 and Table S1). Vertical distribution of the 6 components validated in Dataset 3 is reported in Fig. S8. 


\subsection{DOM behavior during estuarine mixing}

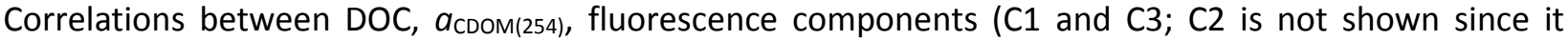
behaves as $\mathrm{C} 1$ ) and salinity are presented in Fig. 5. DOC, $a_{\mathrm{CDOM}(254)}$ and the protein-like component (C3) showed a slight deviation from the conservative mixing line in February and clear non-conservative behavior in July, when a marked increase in all the parameters was observed at intermediate salinity (530) (Fig. 5). In contrast, humic-like substances (C1 and C2) showed conservative behavior. When only the samples collected in the mixing area $(S=1.8-36)$ were taken into consideration, DOC and $a_{\mathrm{CDOM}(254)}$ showed a linear inverse correlation in February and a linear direct correlation in July (Fig. 6).

\subsection{Spectral slope curve}

SSC was suggested by Loiselle et al. (2009) as an alternative approach to study absorption characteristics of CDOM instead of using single (or multiple) spectral slopes values. SSC could be considered as a fingerprint of a sample, from which changes in the spectral slope of absorption spectra can be detected and associated with differences in CDOM composition (Loiselle et al., 2009). The shape of our SSC in RW and SW match well with that reported by Loiselle et al. (2009) and by Massicotte et al. (2017) for different water systems spanning aquatic continuum. Average SSC in SW was higher than average SSC in RW (Fig. 7A). Maximal $S_{\lambda}$ in RW $\left(0.020 \mathrm{~nm}^{-1}\right)$ was obtained at $300 \mathrm{~nm}$, whereas in SW it was at $290 \mathrm{~nm}$ $\left(0.034 \mathrm{~nm}^{-1}\right)$. Due to very low absorbance and high spectral noise, at wavelengths higher than $450 \mathrm{~nm}$, the peaks observed at these wavelengths should be taken with caution, especially in SW, where the signal to noise ratio is very low.

The comparison of SSCs in 3 selected samples showed the occurrence of the peak at $280 \mathrm{~nm}$ in all the samples, but with the highest value in the surface sample collected at station 6 in July (mixing area) and the lowest one in the hypoxic bottom water (Fig. 7B). A pronounced peak at $370 \mathrm{~nm}$, consistent with the strong increase of fluorescence peak at $\lambda_{\mathrm{ex}} / \lambda_{\mathrm{em}}=330 / 380-420 \mathrm{~nm}$ (Fig. 4), was observed in the sample collected in the bloom area in the river (station K4). An additional peak at $340 \mathrm{~nm}$ was observed in the samples collected in the mixing area in July, corresponding to the peak at $\lambda_{\mathrm{ex}} / \lambda_{\mathrm{em}}=315 / 380-420 \mathrm{~nm}$ in EEM (Fig. 4). These two peaks are not visible in the SSCs reported by Massicotte et al. (2017).

\section{Discussion}


Our results show that the Krka River estuary is characterized by two distinct sources of DOM with specific DOM concentrations and optical properties: the river and the sea. Our study also unveils the insitu production of DOM in the estuary and reports new information about the changes in the DOM pool due to photochemical and biological processes.

\subsection{Terrestrial DOM}

The Krka waters, entering the estuary, were characterized by very low DOC concentrations in both seasons, in contrast to most of the rivers all over the world. As a consequence, the river has a "dilution effect" on marine DOM in the estuary. The low $S_{275-295}$, high SUVA $_{254}$ and the high fluorescence of microbial and terrestrial humic-like components ( $\mathrm{C} 1$ and $\mathrm{C} 2$ ) (Table 1 ) indicate that the DOM pool in the RW is mainly constituted by terrestrial substances. In summer, despite the slight decrease in DOC concentrations, absorption and fluorescence, no change was observed in $\mathrm{SUVA}_{254}$ and $S_{275-295}$, indicating that most of the DOM is still terrestrial, even if a small fraction was removed by biological or photochemical processes. The terrestrial origin of DOM in the RW is further supported by the absence of anthropogenic sources of DOM along the river flow (Cukrov et al., 2008). Whereas in most of the rivers

353 anthropogenic substances can interfere with the signal of terrestrial DOM (․ㅡong et al., 2005; Meng et al.,

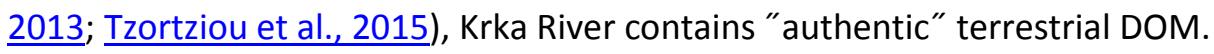

\subsection{Marine DOM}

DOM in SW clearly had a marine signature. DOC values as well as SUVA 254 and $S_{275-295}$ are comparable to 358 those observed in the upper layer $(0-100 \mathrm{~m}$ ) of the Mediterranean Sea (Catala et al., 2018; Galletti et al., 2019; Santinelli, 2015). In SW, DOM was characterized by lower average MW and chromophoric content than in RW as suggested by 2 times higher average $S_{275-295}$ and 3 times lower average SUVA 254 (Table 1). In July, photochemical processes affected the DOM pool resulting in a slight decrease in fluorescence of 362 all the PARAFAC components with respect to February. 
365

In the estuary, DOM showed non-conservative mixing between the two end-members (RW and SW) with values of DOC, $a_{\mathrm{CDOM}(254)}$ and protein-like fluorescence (C3) higher than those expected by linear mixing at a salinity of 5-30 (Fig. 5). This pattern was more apparent in July, when a marked accumulation of DOC, CDOM and C3 occurred. In July, a direct linear correlation was observed between DOC and $a_{\mathrm{CDOM}(254)}$ (Fig. 6), suggesting a net production of both DOC and CDOM. In February, the correlation was inverse, with high values of $a_{\mathrm{CDOM}(254)}$ in correspondence with low DOC concentrations in the RW. This correlation supports that in winter, the main process affecting DOM dynamics in the estuary is the mixing of RW (low DOC and high $\left.a_{\mathrm{CDOM}(254)}\right)$ and SW (high DOC and low $\left.a_{\mathrm{CDOM}(254)}\right)$, even if a slight increase in both DOC and CDOM was observed. These seasonal differences can be explained by the change in river discharge and temperature. In winter, the Krka estuary is dominated by terrestrial DOM due to the high river discharge, whereas in summer, the low river discharge results in extended water residence time, which, combined with the high temperatures, favors primary production (Legovic et al., 1994), leading to in-situ production of DOM. It is noteworthy that in contrast to protein-like fluorescence (C3), humic-like fluorescence ( $\mathrm{C} 1$ and $\mathrm{C} 2$ ) showed a conservative mixing behavior, even if in February a slight removal can be observed at salinity of 5-30 (Fig. 5). The different behavior suggests that the FDOM components are affected by different processes and that they can give information on the main sources of DOM.

In July, the high DOC (up to $147 \mu \mathrm{M}$ ), CDOM and C3 values observed at stations 5-7 (Fig. S5C) can be explained by a decoupling between DOC production and removal processes, combined with the high degree of stratification of the water column, due to the occurrence of a marked halocline at $1.5 \mathrm{~m}$ (Fig. 2C). In the oceans, DOC accumulation is usually observed in high stratified waters (Hansell, 2013; $\underline{\text { Hansell }}$ and Carlson, 2001; Hansell et al., 2009; Santinelli et al., 2013). On one hand, the halocline represents a barrier that separates surface and deep waters, suppressing vertical mixing of DOM, while on the other hand, different processes can explain an increase of production not balanced by removal;

(1) excessive production during the phytoplankton bloom (Legovic et al., 1994). In spring, DOM can be released by active growing phytoplankton (Carlson and Hansell, 2015) as well as by the decomposition of the freshwater phytoplankton that die due to the increase in salinity in the estuary (Vilicic et al., 1989). This hypothesis is supported by Vilicic et al. (1989), who showed that the ratio between chl-a and phaeophytin (chlorophyll degradation product) rapidly decreases at the halocline, suggesting a high proportion of dead phytoplankton in the surface layer. Their microscopic observations confirmed the presence of dead cells along with active phytoplankton in the freshwater-seawater interface. 
396

(2) reduced consumption by prokaryotic heterotrophs. Possible reasons for the lack of bacterial removal are: (i) nutrient limitation, due to the enhanced stratification in summer, which limits the nutrient supply to the surface waters; (ii) stress, caused by the salinity gradient; (iii) high irradiation, inhibiting bacterial growth; (iv) the high optical transparency of surface waters, which can increase the impact of photochemical reactions that may transform DOM from labile to recalcitrant, making it unavailable to bacteria on the short temporal scale (Benner and Biddanda, 1998; jiao et al., 2010; Kieber et al., 1997), (v) high grazing and viral lysis of prokaryotic heterotrophs.

Even if a combination of all the above reported processes can probably explain the non-conservative DOM behavior at the estuary, the high fluorescence of the protein-like component (C3) in the FWL supports the hypothesis that there is a limitation of bacterial growth, since the protein-like components are known to be the most labile fraction of DOM, and are the first that should be removed by active bacteria (Fellman et al., 2011; Hansell, 2013).

Finally, we cannot exclude that atmospheric deposition can represent an important source of DOC to the

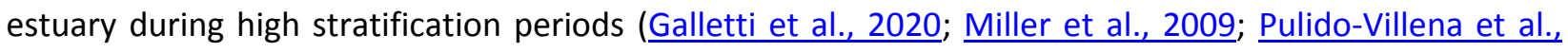
2008; Ternon et al., 2010; Vicente et al., 2012); unfortunately no data about atmospheric deposition in this area is available at the moment.

In other estuarine systems (Gonnelli et al., 2013; Li et al., 2019; Osburn et al., 2012; Retelletti Brogi et al., 2015; Santos et al., 2016; Sempere et al., 2000) the pattern observed in the Krka estuary is masked by the high content of organic matter and the nutrients of riverine waters, that can stimulate the growth of the bacteria enabling them to resist the salinity shock.

\subsection{DOM in the bottom seawater layer in summer}

The bottom seawater layer has some features that make it a very interesting system for the study of DOM dynamics. In July, chl-a vertical distribution indicates that the highest phytoplankton biomass is near the bottom (Fig. 3D). The same pattern has been observed in previous cruises (July 2017 and July 2018) (Figs. S3 and S4) making it a peculiarity of this area. Entering the estuary, the increased salinity causes mortality of freshwater phytoplankton and half of the cells sinks to the bottom before Prokljan Lake, where they serve as a source of DOM for heterotrophic prokaryotes (Legovic et al., 1991b; Petricioli et al., 1996). Mineralization of the DOM releases nutrients making them available for marine phytoplankton below the halocline. The high water transparency allows the light to penetrate to the bottom $(5-30 \mathrm{~m})$. The availability of both, nutrients and light, can stimulate marine phytoplankton 
427 growth, leading to the highest chl- $a$ values close to the bottom. Moving toward the river, DOC increases 428 from $59 \mu \mathrm{M}$ at station 12 to $115 \mu \mathrm{M}$ at station 1 (Fig. S5C and Table 2), suggesting a net production of 429 DOC. DOC accumulation is lower than that observed in the surface layer. This difference can be 430 explained by the different source of DOM, that is marine blooming phytoplankton in bottom layer and 431 mostly dead freshwater phytoplankton in the surface layer. In addition, in the bottom layer, bacterial 432 removal of newly-released DOM is expected to be more active due to the availability of nutrients and the 433 lower light intensity than in the surface layer, where nutrients are limited due to the water column 434 stratification and light is very intense. In the bottom layer, the highest DOC values were observed in 435 correspondence with oversaturation of oxygen (stations 2, 3 and 4) supporting its net production. In the 436 other stations, the production of DOC could be masked by its removal, as suggested by the high values of 437 apparent oxygen utilization (AOU) (Table 2). AOU gives an indirect estimate of the oxygen consumption 438 and can be transformed in C equivalent in agreement with Doval and Hansell (2000) (AOU-C $\mathrm{C}_{\mathrm{eq}}=\mathrm{AOU}$ $439 * 0.72$ ). AOU-C $C_{\text {eq }}$ indicates the amount of DOC that needs to be removed in order to explain the estimated 440 oxygen consumption, assuming that DOC mineralization is the only process that removes oxygen. AOU is 441 high between stations 5 and 10, where, despite the high chl-a, no marked increase in DOC is observed 442 (Table 2). If the AOU-C $C_{\text {eq }}$ is added to the DOC values measured at these stations, we obtain values 443 comparable to those measured at stations 2, 3 and 4 (Table 2), supporting that microbial respiration can 444 explain the discrepancy between the high values of chl-a and the lower than expected increase in DOC. 445 Finally, station 1 is characterized by hypoxia, where different processes affect DOM dynamics. They are 446 discussed in detail in the next paragraph.

\subsection{DOM dynamics in the hypoxic waters}

449 In the inner part of the estuary, oxygen saturation showed values $<75 \%$ in February (Fig. $3 \mathrm{~A}$ ), while in 450 July it decreases below $38 \%$ at station 1 (Fig. 3C). This site is characterized by a specific cuvette shape, in 451 which the residence time of the seawater is increased compared to the adjacent seawater (Cindric et al., 452 2015). In summer, as a result of longer seawater residence time, the sinking of decaying freshwater 453 phytoplankton from the upper layer enhances the effect of bacterial mineralization, causing oxygen 454 depletion. In the case of particularly high production in the Visovac Lake and within the estuary, hypoxia 455 can be observed in late summer and autumn in the shallow part of the estuary (stations 1-5) (Legovic et 456 al., 1991b; Petricioli et al., 1996). In winter, the inflow of the freshwater promotes the seawater renewal 457 and ventilation as it is clearly visible in the oxygen vertical distribution (Fig. 3A). Taking into consideration 458 only the samples with oxygen saturation $<75 \%$, an inverse correlation between oxygen saturation, DOC, 
$a_{\mathrm{CDOM}(254)}, \mathrm{SUVA}_{254}$ and all three PARAFAC components was observed, with a $R^{2}$ values of 0.99 (Fig. S11). Even if the data are not enough for a meaningful investigation of the processes leading to DOM accumulation, the very good correlation suggests that the oxygen removal is coupled with the production of DOM with a high percentage of both CDOM and FDOM in the hypoxic waters. This observation is in agreement with Margolin et al. (2016), who found strong correlations between optical properties and apparent carbon mineralization in anoxic waters in Black Sea. They observed higher increase in CDOM and humic-like FDOM than in DOC, and explained this finding with the release of CDOM during organic matter mineralization or with the microbial transformation of non-chromophoric DOM into CDOM (Margolin et al., 2016).

Our data unveils different processes occurring in the bottom waters. When oxygen was available, DOC was released and removed, whereas in hypoxic waters the production of highly chromophoric DOM was observed.

\section{Conclusion}

Our data show that the Krka River estuary is affected by different sources of DOM (riverine, marine, insitu produced) with distinct optical properties. DOM pool in the river has a very low DOC concentration and it mainly contains terrestrial molecules, as suggested by the high SUVA ${ }_{254}$ and low $S_{275-295}$ values, as well as by the predominance of humic-like substances. DOM in the seawater features the concentration and optical properties of the "typical" marine DOM from open sea waters. In-situ production of DOM is clearly observed in the estuary, leading to non-conservative behavior of the DOM, particularly in summer. The accumulation observed in the freshwater layer in summer is probably due to the low efficiency of heterotrophic prokaryotes in the removal of the produced DOM. Our data also unveils different processes occurring in the bottom waters. When oxygen is available, DOM is released and quickly removed without accumulation, whereas in hypoxic waters the production of DOC, CDOM and FDOM is linearly related to oxygen consumption.

Additional data, such as nutrient concentrations, heterotrophic prokaryotes, phytoplankton, zooplankton and virus abundance as well as heterotrophic prokaryotes production are mandatory in order to explain the non-conservative behavior of DOM in the estuary. For the future, incubation experiments could also give additional information about the biological lability of DOM coming from different sources and investigate its potential impact on the global carbon cycle. 


\section{Acknowledgment}

This research was realized within the scope of the project "New methodological approach to biogeochemical studies of trace metal speciation in coastal aquatic ecosystems" (MEBTRACE), financially supported by the Croatian Science Foundation under the project number IP-2014-09-7530.

\section{Literature}

Beaupré, S.R., 2015. The carbon isotopic composition of marine DOC, Biogeochemistry of marine dissolved organic matter. Elsevier, pp. 335-368.

Benner, R. and Biddanda, B., 1998. Photochemical transformations of surface and deep marine dissolved organic matter: Effects on bacterial growth. Limnology and Oceanography, 43(6): 1373-1378.

Burdige, D.J. and Komada, T., 2015. Sediment pore waters, Biogeochemistry of marine dissolved organic matter. Elsevier, pp. 535-577.

Buzancic, M., Gladan, Z.N., Marasovic, I., Kuspilic, G. and Grbec, B., 2016. Eutrophication influence on phytoplankton community composition in three bays on the eastern Adriatic coast. Oceanologia, 58(4): 302-316.

Carlson, C.A. and Hansell, D.A., 2015. DOM sources, sinks, reactivity, and budgets, Biogeochemistry of marine dissolved organic matter. Elsevier, pp. 65-126.

Catala, T.S., Martinez-Perez, A.M., Nieto-Cid, M., Alvarez, M., Otero, J., Emelianov, M., Reche, I., Aristegui, J. and Alvarez-Salgado, X.A., 2018. Dissolved Organic Matter (DOM) in the open Mediterranean Sea. I. Basin-wide distribution and drivers of chromophoric DOM. Progress in Oceanography, 165: 35-51.

Cetinic, I., Vilicic, D., Buric, Z. and Olujic, G., 2006. Phytoplankton seasonality in a highly stratified karstic estuary (Krka, Adriatic Sea). Hydrobiologia, 555: 31-40.

Cindric, A.M., Garnier, C., Oursel, B., Pizeta, I. and Omanovic, D., 2015. Evidencing the natural and anthropogenic processes controlling trace metals dynamic in a highly stratified estuary: The Krka River estuary (Adriatic, Croatia). Marine Pollution Bulletin, 94(1-2): 199-216.

Coble, P.G., 1996. Characterization of marine and terrestrial DOM in seawater using excitation emission matrix spectroscopy. Marine Chemistry, 51(4): 325-346.

Cukrov, N., Cmuk, P., Mlakar, M. and Omanovic, D., 2008. Spatial distribution of trace metals in the Krka River, Croatia: An example of the self-purification. Chemosphere, 72(10): 1559-1566.

Dainard, P.G., Guéguen, C., McDonald, N. and Williams, W.J., 2015. Photobleaching of fluorescent dissolved organic matter in Beaufort Sea and North Atlantic Subtropical Gyre. Marine Chemistry, 177: 630-637.

Dixon, J.L., Osburn, C.L., Paerl, H.W. and Peierls, B.L., 2014. Seasonal changes in estuarine dissolved organic matter due to variable flushing time and wind-driven mixing events. Estuarine, Coastal and Shelf Science, 151: 210-220.

Doval, M. and Hansell, D.A., 2000. Organic carbon and apparent oxygen utilization in the western South Pacific and the central Indian Oceans. Marine Chemistry, 68(3): 249-264.

Druffel, E.R., Williams, P.M., Bauer, J.E. and Ertel, J.R., 1992. Cycling of dissolved and particulate organic matter in the open ocean. Journal of Geophysical Research: Oceans, 97(C10): 15639-15659.

Fellman, J.B., Petrone, K.C. and Grierson, P.F., 2011. Source, biogeochemical cycling, and fluorescence characteristics of dissolved organic matter in an agro-urban estuary. Limnology and Oceanography, 56(1): 243-256. 
533

534

535

536

537

538

539

540

541

542

543

544

545

546

547

548

549

550

551

552

553

554

555

556

557

558

559

560

561

562

563

564

565

566

567

568

569

570

571

572

573

574

575

576

577

578

579

580
Fichot, C.G. and Benner, R., 2012. The spectral slope coefficient of chromophoric dissolved organic matter (S275-295) as a tracer of terrigenous dissolved organic carbon in river-influenced ocean margins. Limnology and Oceanography, 57(5): 1453-1466.

Fichot, C.G. and Benner, R., 2014. The fate of terrigenous dissolved organic carbon in a river-influenced ocean margin. Global Biogeochemical Cycles, 28(3): 300-318.

Galletti, Y., Becagli, S., di Sarra, A., Gonnelli, M., Pulido-Villena, E., S., D. M., T., R., V., S., and Santinelli, C., 2020. Atmospheric deposition of organic matter at a remote site in the Central Mediterranean Sea: implications for marine ecosystem. Biogeosciences Discuss., under review, DOI:10.5194/bg2020-14.

Galletti, Y., Gonnelli, M., Brogi, S.R., Vestri, S. and Santinelli, C., 2019. DOM dynamics in open waters of the Mediterranean Sea: New insights from optical properties. Deep-Sea Research Part IOceanographic Research Papers, 144: 95-114.

Garcia, H.E., Boyer, T.P., Locarnini, R.A., Antonov, J.I., Mishonov, A.V., Baranova, O.K., Zweng, M.M., Reagan, J.R., Johnson, D.R. and Levitus, S., 2013. World ocean atlas 2013. Volume 3, Dissolved oxygen, apparent oxygen utilization, and oxygen saturation.

Garcia, R.D., Diéguez, M.d.C., Gerea, M., Garcia, P.E. and Reissig, M., 2018. Characterisation and reactivity continuum of dissolved organic matter in forested headwater catchments of Andean Patagonia. Freshwater biology, 63(9): 1049-1062.

Gonnelli, M., Vestri, S. and Santinelli, C., 2013. Chromophoric dissolved organic matter and microbial enzymatic activity. A biophysical approach to understand the marine carbon cycle. Biophysical Chemistry, 182: 79-85.

Grzetic, Z., Precali, R., Degobbis, D. and Skrivanic, A., 1991. Nutrient Enrichment and Phytoplankton Response in an Adriatic Karstic Estuary. Marine Chemistry, 32(2-4): 313-331.

Hansell, D.A., 2005. Dissolved organic carbon reference material program. Eos, Transactions American Geophysical Union, 86(35): 318-318.

Hansell, D.A., 2013. Recalcitrant dissolved organic carbon fractions.

Hansell, D.A. and Carlson, C.A., 2001. Marine dissolved organic matter and the carbon cycle. Oceanography, 14(4): 41-49.

Hansell, D.A., Carlson, C.A., Repeta, D.J. and Schlitzer, R., 2009. Dissolved organic matter in the ocean: A controversy stimulates new insights. Oceanography, 22(4): 202-211.

Helms, J.R., Stubbins, A., Ritchie, J.D., Minor, E.C., Kieber, D.J. and Mopper, K., 2008. Absorption spectral slopes and slope ratios as indicators of molecular weight, source, and photobleaching of chromophoric dissolved organic matter. Limnology and Oceanography, 53(3): 955-969.

Hong, H., Wu, J., Shang, S. and Hu, C., 2005. Absorption and fluorescence of chromophoric dissolved organic matter in the Pearl River Estuary, South China. Marine Chemistry, 97(1-2): 78-89.

Jiao, N., Herndl, G.J., Hansell, D.A., Benner, R., Kattner, G., Wilhelm, S.W., Kirchman, D.L., Weinbauer, M.G., Luo, T. and Chen, F., 2010. Microbial production of recalcitrant dissolved organic matter: long-term carbon storage in the global ocean. Nature Reviews Microbiology, 8(8): 593.

Joshi, I.D., D'Sa, E.J., Osburn, C.L., Bianchi, T.S., Ko, D.S., Oviedo-Vargas, D., Arellano, A.R. and Ward, N.D., 2017. Assessing chromophoric dissolved organic matter (CDOM) distribution, stocks, and fluxes in Apalachicola Bay using combined field, VIIRS ocean color, and model observations. Remote sensing of environment, 191: 359-372.

Kieber, R.J., Hydro, L.H. and Seaton, P.J., 1997. Photooxidation of triglycerides and fatty acids in seawater: Implication toward the formation of marine humic substances. Limnology and Oceanography, 42(6): 1454-1462.

Knežević, L., Cukrov, N. and Bura-Nakić, E., 2019. Ion-exchange chromatography as a tool for investigating vanadium speciation in sediments: preliminary studies. Journal of Soils and Sediments: 1-8. 
581

582

583

584

585

586

587

588

589

590

591

592

593

594

595

596

597

598

599

600

601

602

603

604

605

606

607

608

609

610

611

612

613

614

615

616

617

618

619

620

621

622

623

624

625

626

627
Laureillard, J. and Saliot, A., 1993. Biomarkers in Organic-Matter Produced in Estuaries - a Case-Study of the Krka Estuary (Adriatic Sea) Using the Sterol Marker Series. Marine Chemistry, 43(1-4): 247261.

Lawaetz, A.J. and Stedmon, C.A., 2009. Fluorescence intensity calibration using the Raman scatter peak of water. Applied spectroscopy, 63(8): 936-940.

Lee, M.H., Osburn, C.L., Shin, K.H. and Hur, J., 2018. New insight into the applicability of spectroscopic indices for dissolved organic matter (DOM) source discrimination in aquatic systems affected by biogeochemical processes. Water Research, 147: 164-176.

Lee, S.-A. and Kim, G., 2018. Sources, fluxes, and behaviors of fluorescent dissolved organic matter (FDOM) in the Nakdong River Estuary, Korea. Biogeosciences, 15(4).

Legovic, T., 1991. Exchange of Water in a Stratified Estuary with an Application to Krka (Adriatic Sea). Marine Chemistry, 32(2-4): 121-135.

Legovic, T., Grzetic, Z. and Smircic, A., 1991a. Effects of Wind on a Stratified Estuary. Marine Chemistry, 32(2-4): 153-161.

Legovic, T., Petricioli, D. and Zutic, V., 1991b. Hypoxia in a Pristine Stratified Estuary (Krka, Adriatic Sea). Marine Chemistry, 32(2-4): 347-359.

Legovic, T., Vilicic, D., Petricioli, D. and Zutic, V., 1991c. Subsurface Gonyaulax-Polyedra Bloom in a Stratified Estuary. Marine Chemistry, 32(2-4): 361-374.

Legovic, T., Zutic, V., Grzetic, Z., Cauwet, G., Precali, R. and Vilicic, D., 1994. Eutrophication in the Krka Estuary. Marine Chemistry, 46(1-2): 203-215.

Li, P. and Hur, J., 2017. Utilization of UV-Vis spectroscopy and related data analyses for dissolved organic matter (DOM) studies: A review. Critical Reviews in Environmental Science and Technology, 47(3): 131-154.

Li, Y., Song, G., Massicotte, P., Yang, F., Li, R. and Xie, H., 2019. Distribution, seasonality, and fluxes of dissolved organic matter in the Pearl River (Zhujiang) estuary, China. Biogeosciences, 16(13): 2751-2770.

Loiselle, S.A., Bracchini, L., Dattilo, A.M., Ricci, M., Tognazzi, A., Cozar, A. and Rossi, C., 2009. Optical characterization of chromophoric dissolved organic matter using wavelength distribution of absorption spectral slopes. Limnology and Oceanography, 54(2): 590-597.

Louis, Y., Garnier, C., Lenoble, V., Mounier, S., Cukrov, N., Omanovic, D. and Pizeta, I., 2009. Kinetic and equilibrium studies of copper-dissolved organic matter complexation in water column of the stratified Krka River estuary (Croatia). Marine Chemistry, 114(3-4): 110-119.

Margolin, A.R., Gerringa, L.J.A., Hansell, D.A. and Rijkenberg, M.J.A., 2016. Net removal of dissolved organic carbon in the anoxic waters of the Black Sea. Marine Chemistry, 183: 13-24.

Massicotte, P., Asmala, E., Stedmon, C. and Markager, S., 2017. Global distribution of dissolved organic matter along the aquatic continuum: Across rivers, lakes and oceans. Science of the Total Environment, 609: 180-191.

Meng, F., Huang, G., Yang, X., Li, Z., Li, J., Cao, J., Wang, Z. and Sun, L., 2013. Identifying the sources and fate of anthropogenically impacted dissolved organic matter (DOM) in urbanized rivers. Water research, 47(14): 5027-5039.

Miller, C., Gordon, K.G., Kieber, R.J., Willey, J.D. and Seaton, P.J., 2009. Chemical characteristics of chromophoric dissolved organic matter in rainwater. Atmospheric Environment, 43(15): 24972502.

Mulholland, P., 2003. Large-scale patterns in dissolved organic carbon concentration, flux, and sources, Aquatic ecosystems. Elsevier, pp. 139-159.

Murphy, K.R., Stedmon, C.A., Graeber, D. and Bro, R., 2013. Fluorescence spectroscopy and multi-way techniques. PARAFAC. Analytical Methods, 5(23): 6557-6566. 
628

629

630

631

632

633

634

635

636

637

638

639

640

641

642

643

644

645

646

647

648

649

650

651

652

653

654

655

656

657

658

659

660

661

662

663

664

665

666

667

668

669

670

671

672

673

674

Murphy, K.R., Stedmon, C.A., Wenig, P. and Bro, R., 2014. OpenFluor- an online spectral library of autofluorescence by organic compounds in the environment. Analytical Methods, 6(3): 658-661.

Omanović, D., Santinelli, C., Marcinek, S. and Gonnelli, M., 2019. ASFit-An all-inclusive tool for analysis of UV-Vis spectra of colored dissolved organic matter (CDOM). Computers \& Geosciences, 133: 104334.

Osburn, C., Atar, J., Boyd, T. and Montgomery, M., 2019. Antecedent precipitation influences the bacterial processing of terrestrial dissolved organic matter in a North Carolina estuary. Estuarine, Coastal and Shelf Science, 221: 119-131.

Osburn, C.L., Handsel, L.T., Mikan, M.P., Paerl, H.W. and Montgomery, M.T., 2012. Fluorescence tracking of dissolved and particulate organic matter quality in a river-dominated estuary. Environmental science \& technology, 46(16): 8628-8636.

Pađan, J., Marcinek, S., Cindrić, A.-M., Layglon, N., Garnier, C., Salaün, P., Cobelo-García, A. and Omanović, D., 2019a. Determination of sub-picomolar levels of platinum in the pristine Krka River estuary (Croatia) using improved voltammetric methodology. Environmental Chemistry.

Pađan, J., Marcinek, S., Cindrić, A.-M., Layglon, N., Lenoble, V., Salaün, P., Garnier, C. and Omanović, D., 2019b. Improved voltammetric methodology for chromium redox speciation in estuarine waters. Analytica Chimica Acta, 1089: 40-47.

Parlanti, E., Worz, K., Geoffroy, L. and Lamotte, M., 2000. Dissolved organic matter fluorescence spectroscopy as a tool to estimate biological activity in a coastal zone submitted to anthropogenic inputs. Organic Geochemistry, 31(12): 1765-1781.

Petricioli, D., BakranPetricioli, T., Vilicic, D. and PozarDomac, A., 1996. Freshwater phytoplankton bloom in Visovac lake - A possible cause of benthic mortality in Krka estuary (Adriatic sea, Croatia). Marine Ecology-Pubblicazioni Della Stazione Zoologica Di Napoli I, 17(1-3): 373-382.

Pulido-Villena, E., Wagener, T. and Guieu, C., 2008. Bacterial response to dust pulses in the western Mediterranean: Implications for carbon cycling in the oligotrophic ocean. Global Biogeochemical Cycles, 22(1).

Raymond, P.A. and Spencer, R.G., 2015. Riverine DOM, Biogeochemistry of marine dissolved organic matter. Elsevier, pp. 509-533.

Repeta, D.J., 2015. Chemical characterization and cycling of dissolved organic matter, Biogeochemistry of marine dissolved organic matter. Elsevier, pp. 21-63.

Retelletti Brogi, S., Balestra, C., Casotti, R., Cossarini, G., Galletti, Y., Gonnelli, M., Vestri, S. and Santinelli, C., 2020. Time resolved data unveils the complex DOM dynamics in a Mediterranean river. Science of The Total Environment: 139212.

Retelletti Brogi, S., Gonnelli, M., Vestri, S. and Santinelli, C., 2015. Biophysical processes affecting DOM dynamics at the Arno river mouth (Tyrrhenian Sea). Biophysical Chemistry, 197: 1-9.

Santinelli, C., 2015. Chapter 13 - DOC in the Mediterranean Sea. In: D.A. Hansell and C.A. Carlson (Editors), Biogeochemistry of Marine Dissolved Organic Matter (Second Edition). Academic Press, Boston, pp. 579-608.

Santinelli, C., Follett, C., Brogi, S.R., Xu, L. and Repeta, D., 2015. Carbon isotope measurements reveal unexpected cycling of dissolved organic matter in the deep Mediterranean Sea. Marine Chemistry, 177: 267-277.

Santinelli, C., Hansell, D.A. and d'Alcalà, M.R., 2013. Influence of stratification on marine dissolved organic carbon (DOC) dynamics: The Mediterranean Sea case. Progress in oceanography, 119: 68-77.

Santinelli, C., Nannicini, L. and Seritti, A., 2010. DOC dynamics in the meso and bathypelagic layers of the Mediterranean Sea. Deep Sea Research Part II: Topical Studies in Oceanography, 57(16): 14461459. 
675

676

677

678

679

680

681

682

683

684

685

686

687

688

689

690

691

692

693

694

695

696

697

698

699

700

701

702

703

704

705

706

707

708

709

710

711

712

713

714

715

716

717

718

719

720

Santos, L., Pinto, A., Filipe, O., Cunha, A., Santos, E.B.H. and Almeida, A., 2016. Insights on the Optical Properties of Estuarine DOM - Hydrological and Biological Influences. Plos One, 11(5).

Santos, L., Santos, E., Dias, J., Cunha, A. and Almeida, A., 2014. Photochemical and microbial alterations of DOM spectroscopic properties in the estuarine system Ria de Aveiro. Photochemical \& Photobiological Sciences, 13(8): 1146-1159.

Schlitzer, R., 2002. Interactive analysis and visualization of geoscience data with Ocean Data View. Computers \& geosciences, 28(10): 1211-1218.

Scribe, P., Fillaux, J., Laureillard, J., Denant, V. and Saliot, A., 1991. Fatty acids as biomarkers of planktonic inputs in the stratified estuary of the Krka River, Adriatic Sea: relationship with pigments. Marine Chemistry, 32(2-4): 299-312.

Sempere, R., Charrière, B., Van Wambeke, F. and Cauwet, G., 2000. Carbon inputs of the Rhône River to the Mediterranean Sea: biogeochemical implications. Global Biogeochemical Cycles, 14(2): 669681.

Søndergaard, M., Stedmon, C.A. and Borch, N.H., 2003. Fate of terrigenous dissolved organic matter (DOM) in estuaries: Aggregation and bioavailability. Ophelia, 57(3): 161-176.

Soto Cárdenas, C., Gerea, M., Garcia, P.E., Pérez, G.L., Diéguez, M.C., Rapacioli, R., Reissig, M. and Queimaliños, C., 2017. Interplay between climate and hydrogeomorphic features and their effect on the seasonal variation of dissolved organic matter in shallow temperate lakes of the Southern Andes (Patagonia, Argentina): a field study based on optical properties. Ecohydrology, 10(7): e1872.

Spencer, R.G.M., Hernes, P.J., Ruf, R., Baker, A., Dyda, R.Y., Stubbins, A. and Six, J., 2010. Temporal controls on dissolved organic matter and lignin biogeochemistry in a pristine tropical river, Democratic Republic of Congo. Journal of Geophysical Research: Biogeosciences, 115(G3).

Stedmon, C.A. and Nelson, N.B., 2015. The optical properties of DOM in the ocean, Biogeochemistry of Marine Dissolved Organic Matter. Elsevier, pp. 481-508.

Strmečki, S., Ciglenečki, I., Udovič, M.G., Marguš, M., Bura-Nakić, E., Dautović, J. and Plavšić, M., 2018. Voltammetric study of organic matter components in the upper reach of the Krka River, Croatia. Croatica Chemica Acta, 91(4): 1-8.

Supraha, L., Bosak, S., Ljubesic, Z., Mihanovic, H., Olujic, G., Mikac, I. and Vilicic, D., 2014. Cryptophyte bloom in a Mediterranean estuary: High abundance of Plagioselmis cf. prolonga in the Krka River estuary (eastern Adriatic Sea). Scientia Marina, 78(3): 329-338.

Svensen, C., Vilicic, D., Wassmann, P., Arashkevich, E. and Ratkova, T., 2007. Plankton distribution and vertical flux of biogenic matter during high summer stratification in the Krka estuary (Eastern Adriatic). Estuarine Coastal and Shelf Science, 71(3-4): 381-390.

Svetličić, V., Ẑutić, V. and Tomaić, J., 1991. Estuarine transformation of organic matter: single coalescence events of estuarine surface active particles. Marine chemistry, 32(2-4): 253-267.

Ternon, E., Guieu, C., Loÿe-Pilot, M.-D., Leblond, N., Bosc, E., Gasser, B., Miquel, J.-C. and Martín, J., 2010. The impact of Saharan dust on the particulate export in the water column of the North Western Mediterranean Sea. Biogeosciences, 7(3): 809-826.

Tzortziou, M., Zeri, C., Dimitriou, E., Ding, Y., Jaffé, R., Anagnostou, E., Pitta, E. and Mentzafou, A., 2015. Colored dissolved organic matter dynamics and anthropogenic influences in a major transboundary river and its coastal wetland. Limnology and oceanography, 60(4): 1222-1240.

Vicente, I.d., Ortega-Retuerta, E. and Reche Cañabate, I., 2012. Contribution of dust inputs to dissolved organic carbon and water transparency in Mediterranean reservoirs.

Vilicic, D., Legovic, T. and Zutic, V., 1989. Vertical-Distribution of Phytoplankton in a Stratified Estuary. Aquatic Sciences, 51(1): 31-46. 
721 Yamashita, Y., Panton, A., Mahaffey, C. and Jaffé, R., 2011. Assessing the spatial and temporal variability of dissolved organic matter in Liverpool Bay using excitation-emission matrix fluorescence and parallel factor analysis. Ocean Dynamics, 61(5): 569-579.

724 Zhou, Y., Li, Y., Yao, X., Ding, W., Zhang, Y., Jeppesen, E., Zhang, Y., Podgorski, D.C., Chen, C. and Ding, Y., 2019. Response of chromophoric dissolved organic matter dynamics to tidal oscillations and anthropogenic disturbances in a large subtropical estuary. Science of the Total Environment, 662: 769-778. 


\section{Figure captions}

Figure 1. Map of the Krka River Estuary with indicated sampling stations. The diamonds refer to the stations where only surface and bottom samples were collected, whereas the triangles indicate the stations where samples were collected at 6 depths. The lower panel shows the shape of the bottom depth with the indication of sampling stations and specific regions. Stations K1-K6 are located in the river preceding the Skradinski Buk waterfall; they are not included in this map, but they are reported in Fig. S2.

Figure 2. Vertical distribution of salinity and temperature in the estuary in February and July 2019. The numbers on the top of the panels indicate the sampling stations and the black dots indicate the sampling points used for the interpolation. Plotted height of the waterfall is lower than in reality $(46 \mathrm{~m})$ for better representation.

Figure 3. Vertical distribution of oxygen saturation and chlorophyll $a$ distribution in the estuary in February and July 2019. The numbers on the top of the panels indicate the sampling stations and the black dots indicate the sampling points used for the interpolation. Plotted height of the waterfall is lower than in reality $(46 \mathrm{~m})$ for better representation.

Figure 4. EEMs of selected samples. The positions of peaks A, M, C, B and T as named by Coble (1996) are reported on each EEM.

Figure 5. Relationship between salinity and A) DOC, B) absorption coefficient at $254 \mathrm{~nm}$ $\left.\left(a_{\mathrm{CDOM}(254)}\right), \mathrm{C}\right)$ microbial humic-like (C1) and D) protein-like component (C3). Dashed lines indicate the theoretical mixing lines (conservative behavior) between the 2 end-members (SW and RW) in February (blue) and July (red) 2019. Theoretical linear mixing line was calculated by linear regression between the two end-members (RW and SW; refer to Table 1 for the values).

Figure 6. Relationship in the mixing area (samples characterized by $S=1.8-36$ ), between DOC and absorption coefficient at $254 \mathrm{~nm}\left(a_{\mathrm{CDOM}(254)}\right)$ in February (blue) and July (red) 2019. Regression lines are plotted as blue and red dashed lines.

Figure 7. A) Spectral slope curves calculated on averaged absorption spectra of freshwater and seawater samples and B) spectral slope curves calculated on absorption spectra of three selected samples. 

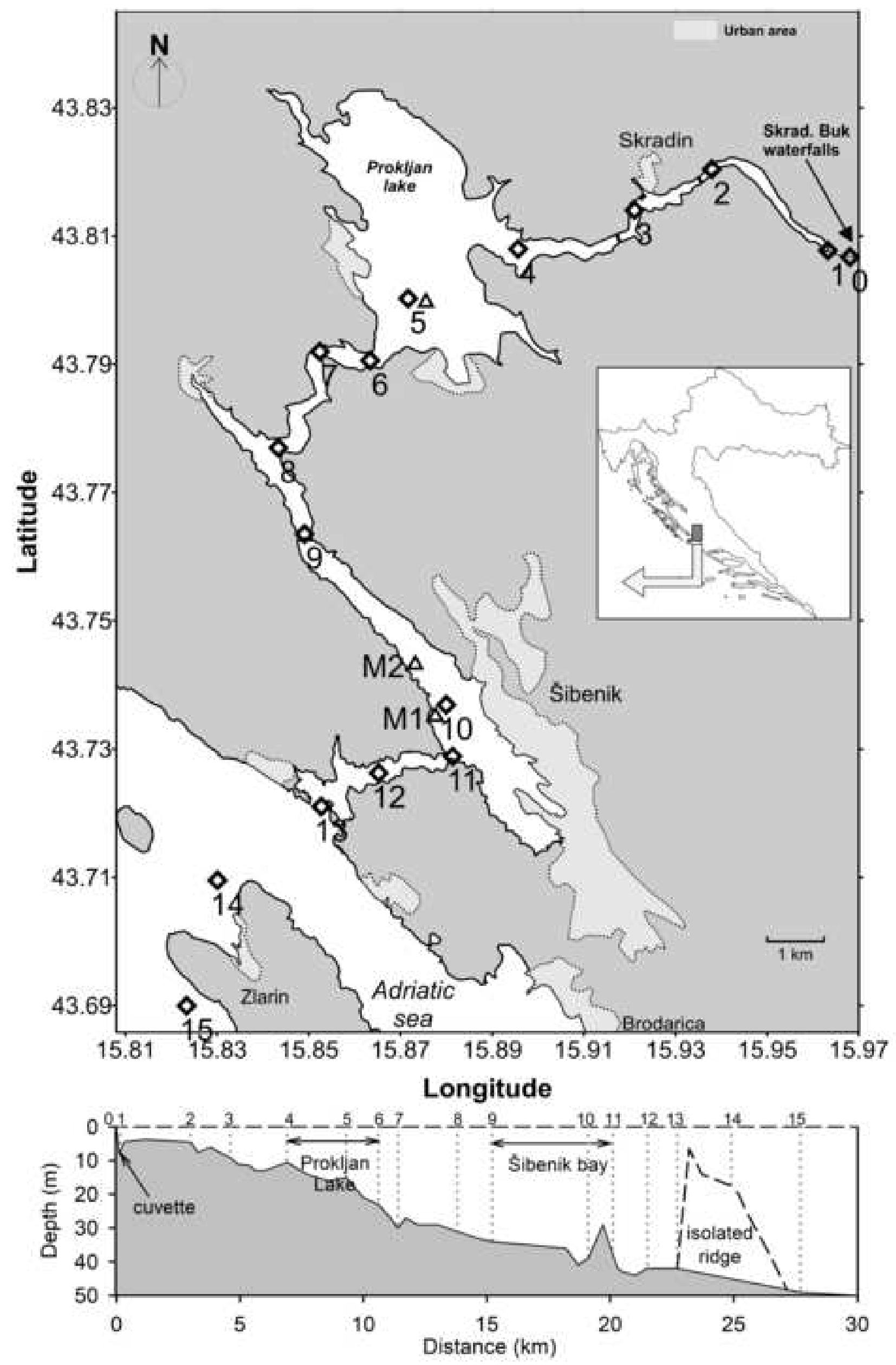

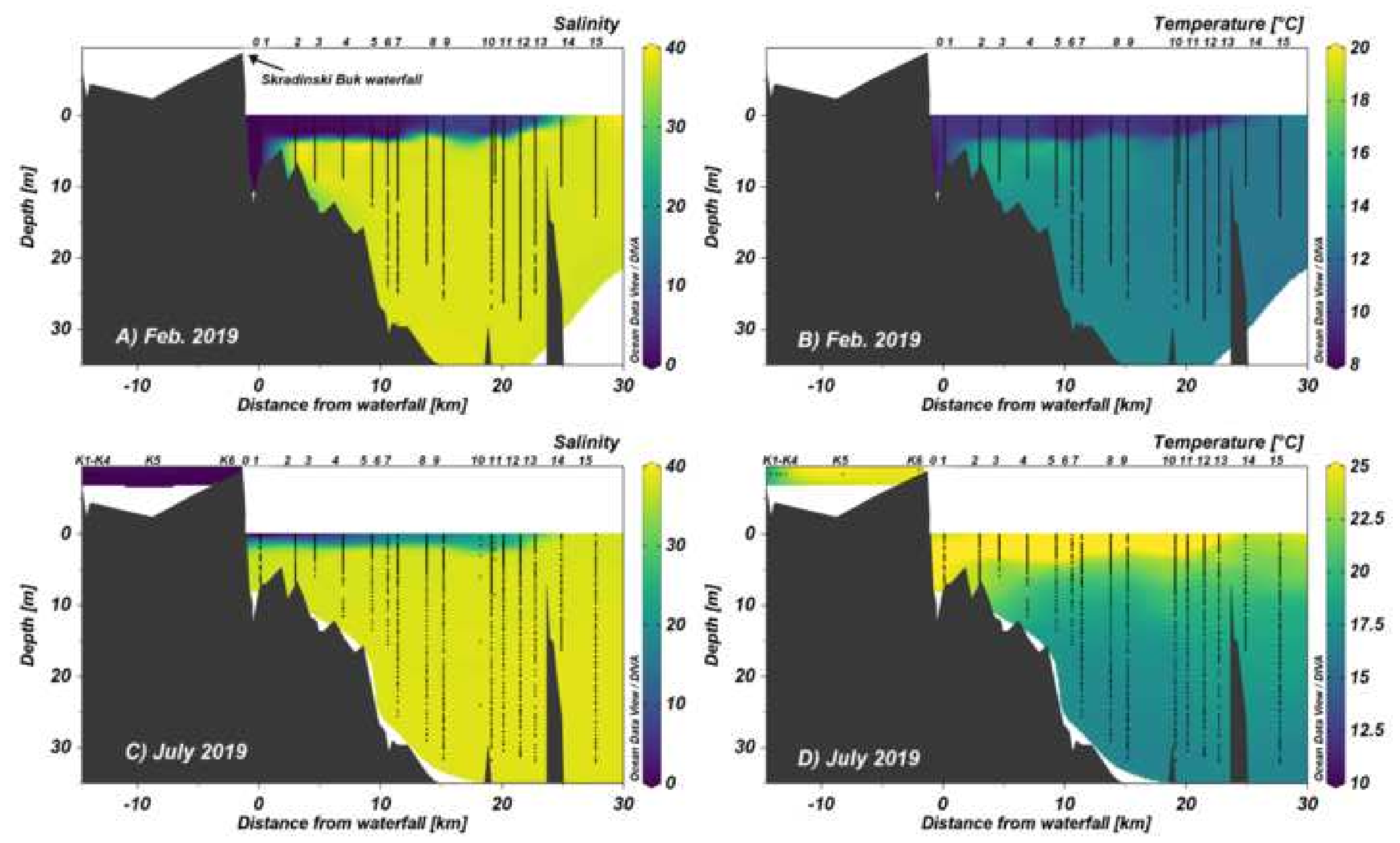

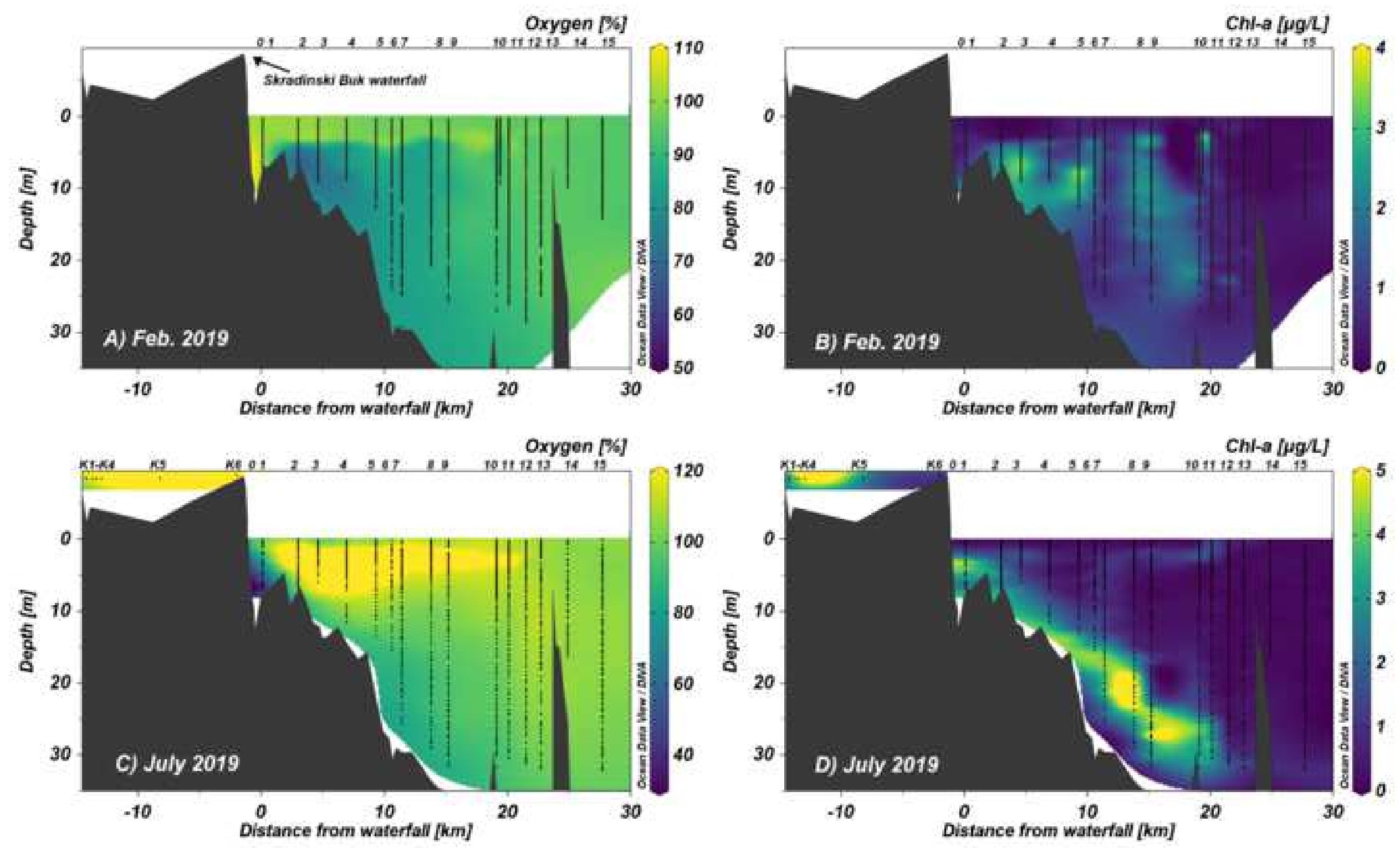

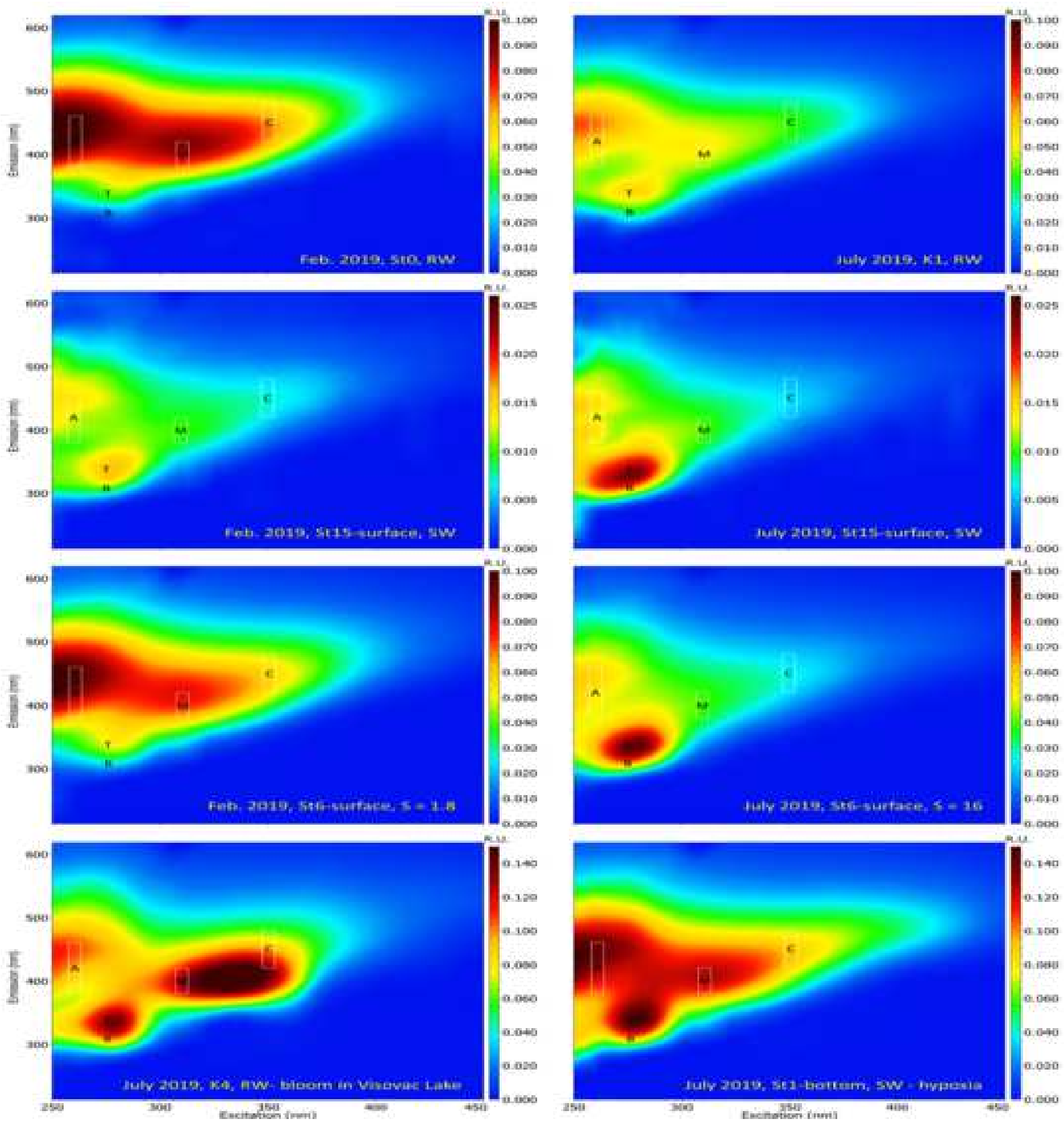

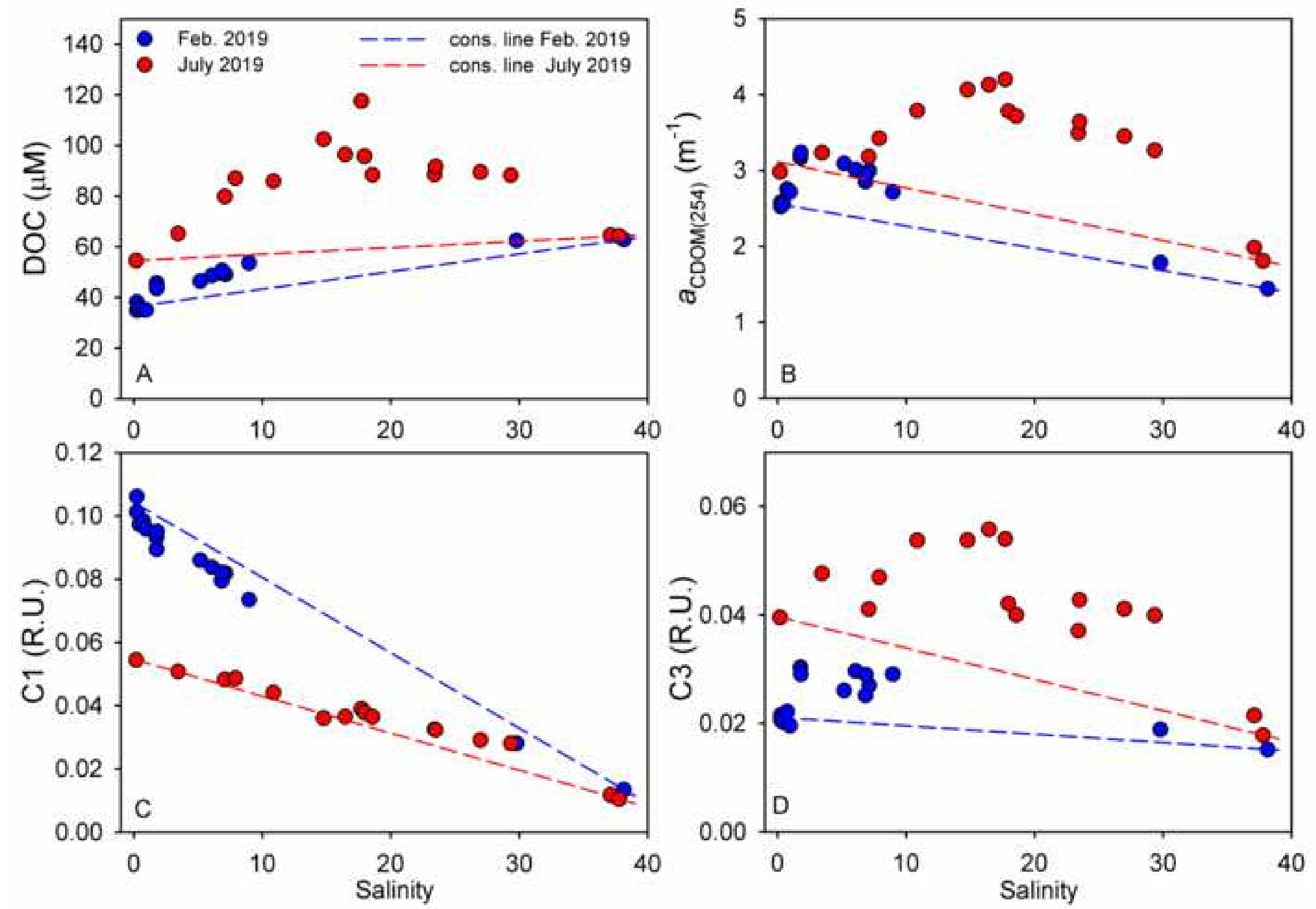


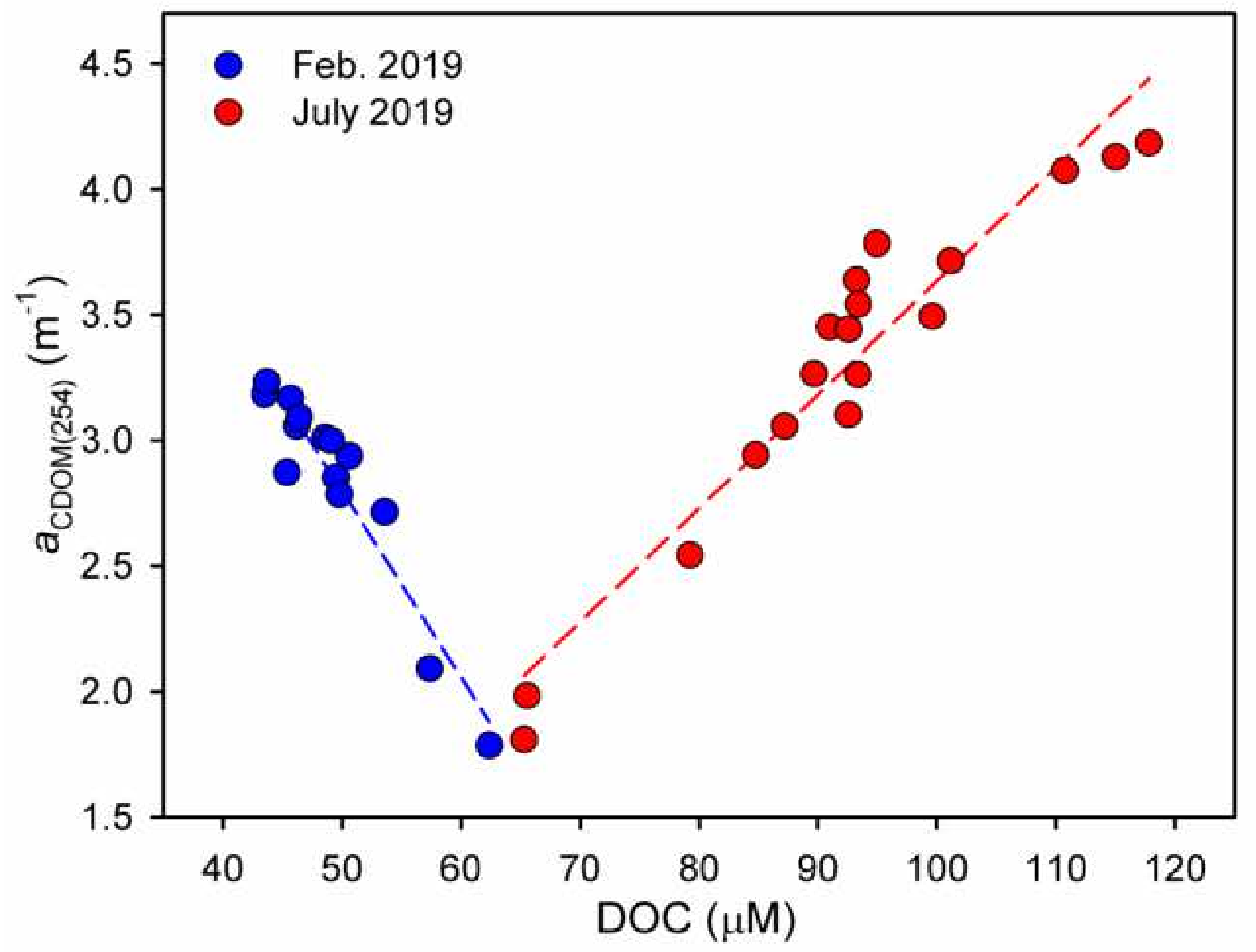



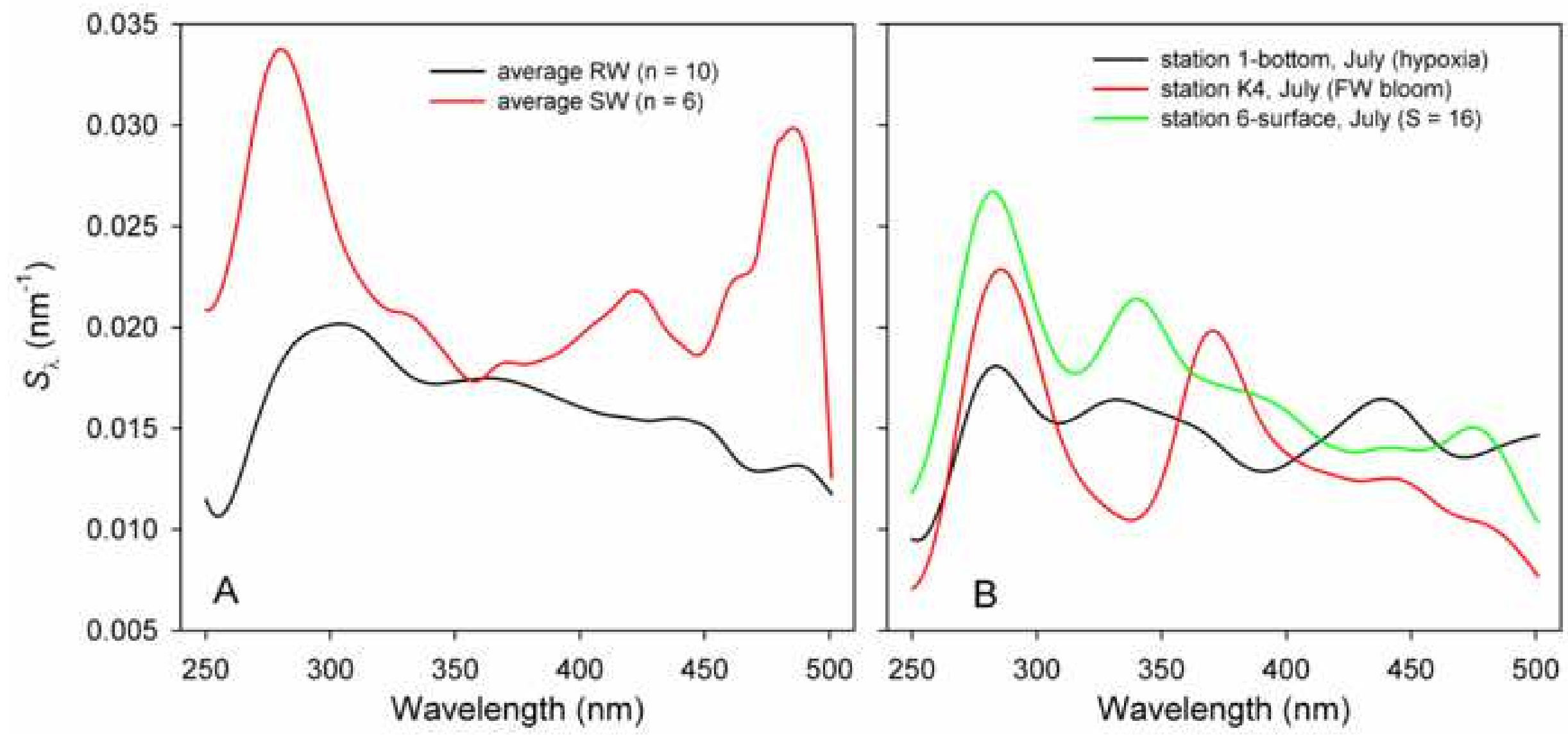
Click here to access/download Table SM_CDOM_Krka_Tables_R1_cln.docx 
Click here to access/download Table SM_CDOM_Krka_SuppDocument_R1_cln.pdf 